\title{
Język nienawiści w dyskursie medialnym
}

\section{Wstęp}

Niniejszy artykuł jest próbą poszukiwania odpowiedzi na pytanie, czy tzw. język nienawiści w mediach ma charakter relacjonowania faktów i odzwierciedlania rzeczywiści społecznej i kulturowej, czy też realizuje inne cele, np. perswazyjnego i manipulacyjnego kreowania pożądanej rzeczywistości wpisanego w funkcjonalność komercyjną i perswazyjną mediów.

Współczesny dyskurs medialny i polityczny ma charakter językowy i metajęzykowy. Język mediów z jednej strony odzwierciedla prymitywność i brutalność dyskursu publiczno-politycznego, a z drugiej strony sam przyczynia się do tabloidyzacji komunikowania społecznego. Jednym z elementów tego zjawiska jest tzw. język nienawiści, którym etykietuje się wybrane wypowiedzi, czyny, postawy i działania życia publicznego, co jest zjawiskiem coraz częściej stosowanym na poziomie metajęzykowym, oceniającym język mediów.

Te dwa poziomy publicznego dyskursu, językowy i metajęzykowy, coraz częściej się przenikają, zacierając granice pomiędzy tym, co jest językowym opisem rzeczywistości a metajęzykowym tworem performatywnym.

Zjawisko to jest widoczne szczególnie w kontekście nienawiści obecnej w życiu publicznym. Odbiorca mediów nie może jednak klarownie odczytać różnicy pomiędzy opisem faktycznych nienawistnych relacji życia publicznego a językowym etykietowaniem niewygodnych dla przeciwnej strony dyskursu wypowiedzi, klasyfikowanej jednoznacznie jako ,język nienawiści”.

Niniejsze analizy są próbą ukazania niektórych manipulacyjnych tendencji w używaniu etykiety ,język nienawiści”. Autor próbuje się skonfrontować z pytaniem, czy takowe etykietowanie ma na celu oczyszczanie życia publicznego z językowych przejawów nienawiści, czy też bardziej chodzi w takim etykietowaniu o to, by kreować czy wyzwalać nienawiść potrzebną do zasilania i karmienia medialnego show. Staram się z perspektywy aksjologii mediów, a także

*Ks. dr hab, prof. UPJPII, e-mail: michal.drozdz@upjp2.edu.pl; Uniwersytet Papieski Jana Pawła II w Krakowie, Wydział Nauk Społecznych, Instytut Dziennikarstwa i Komunikacji Społecznej; 31-004 Kraków, ul. Grodzka 40. 
z perspektywy semiologicznej i lingwistyki medialnej, odpowiedzieć na pytanie, jaką rolę odgrywa język medialny w kształtowaniu i promowaniu realnych postaw wrogości i nienawiści, i odwrotnie - w jaki sposób tendencje kulturowo-medialne kształtują medialny język nienawiści. Nie będę się zajmował zasadniczo analizą materialnej strony języka, ale raczej spróbuję spojrzeć krytycznie na pewne tendencje medialne kształtujące nowe formy językowe będące nośnikiem negatywnych wartości.

\section{Mowa nienawiści w kontekście wolności słowa}

Nie wchodząc w etyczne szczegóły rozumienia nienawiści jako wartości negatywnej przeciwnej miłości i dobru człowieka, warto krótko uporządkować przedpole refleksji.

Nienawiść nie jest tylko kwestią emocjonalnej antypatii, ale jest wyrazem dobrowolnego odrzucenia drugiego człowieka w postawie, języku i działaniu.

Naturę nienawiści określa cel odrzucenia drugiego człowieka: albo ze względu na zagrożenie dla mnie (odium abominationis), albo odczuwam odrazę ze względu na drugiego, życząc mu zła (odium inimicitiae). W jednym i drugim przypadku przekreślam wartość i godność drugiego człowieka.

Ten, kto odczuwa spontaniczną antypatię wobec kogoś dlatego, że popełnił on jakieś wielkie zło albo wyrządził innym krzywdę, doświadcza wewnętrznego bólu, ale nie nienawidzi. Również ten, kto potępia zło, które jest w bliźnim, bo jest przez niego spełniane, nie ganiąc jednak jego osoby, nie nienawidzi. Dezaprobata tego, co rzeczywiście w bliźnim jest złem i złośliwością stanowi nawet część prawdziwej miłości bliźniego.

W dyskursie publiczno-medialnym pojawiło się ostatnio pojęcie tzw. mowy nienawiści. Pojęcie to dokładnie wpisuje się w mechanizm etykietowania poglądów przeciwników. W 2003 roku ukazała się książka Sergiusza Kowalskiego i Magdaleny Tulli Zamiast procesu. Raport o mowie nienawiści ${ }^{1}$. Jest to bogato udokumentowana praca na temat mowy nienawiści zawartej w prawicowych mediach. Książka ujawnia produktywność analityczną perspektywy, jaką wyznacza mowa nienawiści. Ta analiza ma jednak podstawową wadę, gdyż identyfikuje mowę nienawiści tylko po stronie poglądów prawicowych. Autorzy tej książki stosują to pojęcie, głównie opisując działania prawicowych mediów, nie zwracając jednocześnie uwagi na stosowanie języka odpowiadającego definicji mowy nienawiści przez inną opcję polityczną, przeważnie lewicową. Takie ujęcie

${ }^{1}$ S. Kowalski, M. Tulli, Zamiast procesu. Raport o mowie nienawiści, W.A.B, Warszawa 2003. 
odzwierciedla ogólną tendencję, w której termin „mowa nienawiści” często jest wykorzystywany nierzetelnie i instrumentalnie, zwłaszcza przez niektóre środowiska polityków, często w manipulacyjny sposób, przejawiający się w tym, że to samo słowo wypowiedziane przez przeciwników politycznych jest piętnowane, a w ustach stronników jest aprobowane jako przejaw elokwencji i oczytania.

$\mathrm{W}$ analizie dyskursu o mowie nienawiści rodzą się następujące podstawowe pytania:

- Czy mowa nienawiści to wyrażanie osobistych opinii, czy narzędzie podsycania nienawiści?

- Czy wyrażanie każdej, nawet skrajnej opinii jest dobre dla debaty publicznej?

Debata na temat mowy nienawiści obejmuje kwestie związane $\mathrm{z}$ konfliktem między dwoma wartościami: wolnością słowa i szacunkiem dla godności człowieka. Według badań CBOS tylko „16\% respondentów uważa, że «Wolność słowa gwarantuje możliwość swobodnego wypowiadania opinii, nawet jeśli te opinie są odczuwane przez pewne osoby lub grupy jako obraźliwe, wyszydzające lub krzywdzące», podczas gdy większość (73\%) nie podzielała tego poglądu"”.

W dyskusji o wolności mediów pojawiają się czasem głosy ignorancji, niezrozumienia. Przykładem takiego głosu niech będzie wypowiedź publicysty jednego $\mathrm{z}$ wielkich dzienników:

Uważam jednak, że jeśli ktoś jest zwolennikiem wolności słowa, to musi być także zwolennikiem wolności słowa obrzydliwego, paskudnego, głupiego, szkodliwego. Ktoś, kto twierdzi, że jest zwolennikiem wolności słowa, ale po warunkiem, że będzie to słowo piękne, mądre, szlachetne, jest $\mathrm{w}$ istocie zwolennikiem cenzury33.

Nazywanie odpowiedzialnego działania etycznego cenzurą graniczy z absurdem. Etyka to nie cenzura. Etyka odzwierciedla i chroni świat wartości, chroni przede wszystkim wartość i godność człowieka.

Thomas Jefferson, współtwórca tzw. Pierwszej Poprawki do Konstytucji Stanów Zjednoczonych, od początku nie miał złudzeń, iż wolność słowa będąca dobrem, może także służyć złu. Oto fragment jego wypowiedzi, gdy był już prezydentem:

Ubolewam nad zgnilizną opanowującą gazety i nad zjadliwością, wulgarnością i zakłamaniem ludzi, którzy w nich piszą... To łajno w szybkim tempie deprawuje opinię

\footnotetext{
${ }^{2}$ CBOS, Społeczna percepcja przemocy i mowy nienawiści. Komunikat z badań, http://www. cbos.pl/-SPISKOM.POL/2007/K_074_07.PDF [dostęp: 14.06.2015].

${ }^{3}$ W. Orliński, Wolność stowa, także kłamliwego, „Gazeta Wyborcza” 2006, 1.03, s. 19.
} 
publiczną. Jest to jednak zło, na które nie ma lekarstwa: warunkiem naszych swobód jest wolność prasy, a tej nie można ograniczyć, nie niszcząc jej

Jefferson - jak wówczas i dziś wielu liberałów i demokratów - nie widział lekarstwa na zło mediów. Lek jednak istnieje: wolność słowa musi być ściśle związana z odpowiedzialnością za słowo, czyli musi być ograniczona dobrem innych. Więcej nawet - dziś większość znawców uważa, że wolność bez odpowiedzialności nie jest wolnością w ogóle.

Wolność mediów, która może urastać do rangi mitu, w świadomości wielu czytelników, słuchaczy i widzów utożsamiana jest automatycznie z prawdziwością i obiektywizmem informacji. Media powinny być wolne (nie oceniam tutaj stanu faktycznego mediów w Polsce, ale podkreślam postulatywny charakter tego twierdzenia), ale to nie znaczy, że mogą być wolne od odpowiedzialności.

Żadna wolność, w tym także wolność wypowiadania się, nie jest absolutna: napotyka bowiem granicę w postaci obowiązku poszanowania godności i uprawnionej wolności innych. Nie należy pisać, tworzyć i nadawać programów, jeśli wyrządza to szkodę prawdzie: mam tu na myśli nie tylko prawdę o faktach, o których informujecie, ale także ,prawdę o człowieku”, godność człowieka we wszystkich jego wymiarach ${ }^{5}$.

Papieska Rada ds. Środków Społecznego Przekazu w dokumencie Etyka $w$ mediach pisze:

Należy zawsze popierać wolność wyrazu opinii, gdyż „kiedy ludzie idą za swoją naturalną skłonnością do wymiany idei i wyrażają swoje poglądy, nie tylko korzystają ze swego prawa. Spełniają oni równocześnie społeczny obowiązek” („Communio et progressio", 45). Wszakże to założenie rozpatrywane w perspektywie etycznej nie stanowi normy absolutnej i niezmiennej. Istnieją oczywiste przypadki: zniesławienie, oszczerstwo, kalumnia, podżeganie do nienawiści i konfliktów między jednostkami i grupami, formy obscenii i pornografii, chorobliwe obrazy przemocy - gdzie nie obowiązuje żadne prawo do ich przekazywania. Równie pewne jest to, że prawo do wolnego przekazywania opinii winno zawsze respektować takie zasady, jak prawda, sprawiedliwość i poszanowanie życia prywatnego ${ }^{6}$.

W czasie pielgrzymki do Polski w 1991 roku Jan Paweł II mówił o odpowiedzialności za słowo:

${ }^{4}$ M. Iłowiecki, Pilnowanie strażników. Etyka dziennikarska w praktyce, Fronda PI, Warszawa 2012, s. 158.

${ }_{5}^{5}$ Por. Jan Paweł II, Prawdziwi chrześcijanie i znakomici dziennikarze, http://www.opoka.org.pl/ biblioteka/W/WP/jan_pawel_ii/przemowienia/dziennikarze_04062000.html [dostęp: 20.09.2006].

${ }^{6}$ Papieska Rada ds. Środków Społecznego Przekazu, Etyka w mediach, Watykan 2000, nr 23. 
[...] więc jest szczególna odpowiedzialność za słowa, które się wypowiada, bo one mają moc świadectwa, albo świadczą o prawdzie, albo są dla człowieka dobrem, albo też nie świadczą o prawdzie, są jej zaprzeczeniem i wtedy są dla człowieka złem, chociaż mogą być tak podawane, tak przepracowane, żeby robiły wrażenie, że są dobrem. To się nazywa manipulacja ${ }^{7}$.

Manipulacja nie jest pojęciem jednoznacznym, dlatego też niejednoznaczna, a nawet kontrowersyjna bywa jej ocena. Przy moralnej ocenie manipulacji należy zwrócić uwagę na zamierzony cel i obraną do niego drogę. Są to niejako moralne znamiona faktu manipulacyjnego. Każdy rodzaj i charakter manipulacji, jakikolwiek by on był, jest w gruncie manipulacją człowiekiem, co implikuje zasadniczo negatywną etycznie ocenę takich działań. Podmiotem manipulacji jest człowiek. Decyduje o tym specyfika manipulacji oraz jej rosnąca różnorodność. Manipulacja jest to celowe i skryte działanie, przez które narzuca się jednostce lub grupie ludzi fałszywy obraz pewnej rzeczywistości.

Medialny język nienawiści służy niestety procesom manipulacyjnym, nie odzwierciedlając rzeczywistości, ale ją kreując, czego przykład mamy w quasi-dokumentach: docu styles, docu soap, docu show, np. Trudne sprawy itd.

\section{Medialne kreowanie sztucznego świata nienawiści}

W ocenie języka nienawiści obecnego w mediach nie może zabraknąć wiedzy na temat funkcjonalności mediów.

Media coraz aktywniej uczestniczą, obok tradycyjnej swojej funkcji odzwierciedlenia świata, w kreowaniu rzeczywistości. Rezultatem tego procesu jest zmiana kompetencji twórców i odbiorców przekazów medialnych. Twórca i nadawca przekazu treściowego nie przekazuje w nim obiektywnego sensu, ale zostaje zredukowany do roli twórcy kontekstów dla odbiorczej kreacji świata i staje się jednym z kontekstów interpretacyjnych.

Medialna wirtualizacja rzeczywistości polega na permanentnym konfrontowaniu „realności dnia codziennego” z „realnością mediów”. Człowiek ciągle doświadcza, poprzez media, sztucznych światów. Doświadczenie to zaczyna kwestionować wyłączność realnego świata, a następnie rozmywać poczucie realności, tak że ,czysty podział na realność codzienną i realność mediów nie jest już możliwy". Długofalowym efektem działania medialnego języka nienawiści jest

${ }^{7}$ Jan Paweł II, Homilia wygłoszona w czasie Mszy św. w Olsztynie, 6 czerwca 1991 roku, [w:] Jan Paweł II, Pielgrzymki do Ojczyzny. Przemówienia i homilie, wyd. 3, Wydawnictwo Znak, Kraków 2005, s. 669. 
kreowanie sztucznych światów nienawiści, które dokonuje się na kilku etapach i poprzez kilka różnych procesów medialnych.

Po pierwsze, realna rzeczywistość jest modelowana według zasad mediów. Medialny język nienawiści nabiera cech performatywnych, kreujących sztuczny świat nienawiści medialnej, przenikającej realny świat relacji międzyludzkich (media odpowiedzialne za emocje nienawiści, np. w ocenie przeciwników politycznych).

Po drugie, świat medialny i realność rzeczywistości wzajemnie się przenikają, relatywizując i zacierając coraz bardziej granice rzeczywistości. Odbiorca mediów traci kryteria odróżniania pomiędzy rzeczywistością nienawiści, a jej medialnym przedstawieniem i opisem.

Po trzecie, media oddziałują na sam kształt rzeczywistości. Wiele realnych wydarzeń politycznych jest dzisiaj od początku inscenizowanych ze względu na możliwość ich prezentacji w mediach. Media kształtują realne emocjonalne stany nienawiści w rzeczywistości pozamedialnej, która jest coraz bardziej przesiąknięta elementami medialnego języka nienawiści.

Po czwarte, media zmieniają uwarunkowania czasowo-przestrzenne realnego życia człowieka oraz jego komunikacyjnych możliwości. Dzięki mediom powstaje struktura wszechobecności bez obecności wyróżnionej. Przestrzeń i czas, tradycyjnie podstawowe współrzędne naszego świata, stają się w tym układzie marginalne. Zmiana tych uwarunkowań potwierdza tezę, iż rzeczywistość medialnej nienawiści polityki jest $\mathrm{w}$ dużej mierze konstrukcją medialną.

Po piąte, media zamazują granicę między realnością a inscenizacją i symulacją. Doświadczenie symulacji staje się coraz częściej wzorem dla zachowań realnych, a realność ocenia się coraz częściej zgodnie z wyobrażeniem medialnego przedstawienia. Stąd może wyrastać przekonanie, że nienawiść symulowana, medialnie przedstawiona jest treścią realnego życiå ${ }^{8}$.

Ten mechanizm oraz te możliwości nowych mediów elektronicznych są wykorzystywane przez różne grupy oraz struktury społeczne i kulturowe do kreowania własnego wizerunku. Za kulisami spektaklu, rozgrywającego się za pośrednictwem mediów, kryją się konstruktywistyczne założenia i narzędzia tworzenia „sztucznych światów”, które - owszem - spełniają pozytywną rolę, służąc na przykład zabawie i rozrywce, natomiast wykorzystywane w strukturach społecznych mogą się stać narzędziem manipulacji.

$\mathrm{W}$ analizie konstruktywistycznych tendencji kreowania medialnego języka nienawiści, nie można nie dostrzec faktu kulturowego wpływu na te tendencje myśli postmodernistycznej, negującej obiektywny związek między znakiem i jego znaczeniem. Jacques Derrida i Jean Baudrillard negują istnienie znacze-

${ }^{8}$ Zob. M. Drożdż, Logos i ethos mediów. Dyskurs paradygmatyczny filozofii mediów, Wydawnictwo Diecezji Tarnowskiej Biblos, Tarnów 2005, s. 328-334. 
nia samego w sobie ${ }^{9}$. Zgodnie z taką koncepcją znak i symbol nie odnoszą się do żadnej rzeczywistości oznaczanej. Nie istnieje zatem żadna rzeczywistość obiektywna, doświadczenie zewnętrzne, poza samym procesem oznaczania, ponieważ każde doświadczenie czy każda rzeczywistość jest tylko efektem dyskursu semantycznego, prowadzonego w całym procesie oznaczania. Język nie jest zatem nośnikiem obiektywnych znaczeń, ale staje się narzędziem dyskursu komunikacyjnego, w którym pojawia się cały szereg dowolnych, konstruowanych przez podmioty komunikacji. Tak język medialny staje się w konsekwencji narzędziem gry, dyskursu, dowolności i subiektywności ludzkich konstrukcji myślowych oraz autonomiczności w ich konstruowaniu, poznawaniu i praktycznym stosowaniu. W ten sposób można bez żadnych zobowiązań i odpowiedzialności kreować medialną mowę nienawiści, która jest swoistą grą negatywnymi wartościami.

\section{Niektóre odsłony językowej destrukcji}

W masowej kulturze medialnej odzwierciedlają się pewne negatywne tendencje mentalności kulturowej, promujące banalność, wulgarność, prymitywność, absolutną swobodę itp. Tendencje te przyczyniają się niewątpliwie do zacierania granic między dobrem a złem, pogłębiając stan zamieszania etycznego. Ta tendencja ma negatywny wpływ na wrażliwość moralną człowieka, tak iż wielu ludzi nie operuje już w języku codziennym pojęciem zła, ale nazywa je pojęciami zastępczymi: niestosownością, brakiem kultury, nielojalnością, niesubordynacją, naruszaniem porządku itp., które częściowo usprawiedliwiają zło lub je banalizują. Media posługują się tak zwaną metodą widoczności, eksponując często w nadmiarze zjawiska negatywne, czyniąc z nich główną siłę własnej atrakcyjności. Konsekwencją takiego działania może być postępujące lekceważenie i banalizacja zła. Proces ten może prowadzić do hipertrofii niewrażliwości na zło, to znaczy, że następuje systematyczna substytucja tego, co dobre, na gorsze, gorszego na złe, nadmiaru na zwyczajność, zwyczajności na nienormalność itd., substytucja, która w końcu zaciera granice pomiędzy dobrem a złem. Substytucja tego typu jest tym łatwiejsza, że służy jej język banalizujący zło, np. słowo „,zabić” zastępowane jest wyrażeniem „,zadawanie śmierci z litości”, „kradzież” jest określana jako „zabranie rzeczy”, „kłamstwo” jako „niewyjaśnialna sprawa”, „zniewolenie” jako „kształtowanie nowej wyobraźni”, „pornografia” jako ,,język ciała”. Ta praktyka językowa nie świadczy o tym, iż zanika świadomość zła, ale raczej o tym, iż zło jest banalizowane oraz że zanika zdolność prawidłowego

\footnotetext{
${ }^{9}$ Zob. M. Drożdż, Media. Teorie i fikcje, Wydawnictwo Jedność, Kielce 2005, s. 53-86.
} 
wartościowania etycznego. Widzimy czasem, jak dopiero tragedie i afery budzą sumienia $\mathrm{z}$ tego zamętu wartościowania etycznego.

Papieska Rada ds. Środków Społecznego Przekazu w dokumencie Etyka $w$ mediach pokazuje potencjalne przestrzenie medialnych zagrożeń, pośród których mowa nienawiści odgrywa szczególnie negatywną rolę:

Media mogą być także wykorzystywane w taki sposób, że paraliżują wspólnotę i szkodzą integralnemu dobru ludzi. Czynią to, gdy prowadzą do wyobcowania ludzi, spychają ich na margines życia społecznego i izolują; gdy wciągają ich w szkodliwe wspólnoty, skupione wokół fałszywych, destrukcyjnych wartości; gdy rozniecają wrogość i konflikty, demonizując innych i kształtując mentalność opartą na przeciwstawieniu ,my” i „oni”; gdy ukazują w pozytywnym świetle to, co niegodziwe i degradujące, natomiast ignorują lub umniejszają to, co doskonali i uszlachetnia; gdy rozpowszechniają informacje bałamutne i fałszywe, skupiając uwagę na sprawach nieważnych i banalnych. Tworzenie stereotypów - opartych na rasie, narodowości, płci, wieku i innych czynnikach, w tym także religii - jest praktyką niepokojąco powszechną w mediach ${ }^{10}$.

Rozniecanie wrogości dokonuje się w mediach przede wszystkim przez język nienawiści, który zawsze będzie wbrew zasadom etyki mediów.

Medialny język nienawiści służy także medialnemu show. Przekaz mediów, przekaz informacyjny jest tworzony w konwencji rozrywki: radio - dynamika spłaszczania faktów, telewizja - show, prasa - tabloidy. Tę medialną „zabawę na śmierć" i tryumf ,technopolu” sugestywnie przedstawia w swoich publikacjach Neil Postman.

Mówienie, że telewizja to rozrywka - pisze Postman - jest oczywiście zwykłym banałem. Fakt ten nie stanowi bynajmniej zagrożenia dla kultury. Może być nawet powodem do radości. Życie nie jest, jak z upodobaniem powtarzamy, gościńcem usłanym kwiatami. [...] Ja jednak nie twierdzę, że telewizja jest rozrywką, ale że uczyniła ona z rozrywki naturalny format, w którym przedstawia wszelkie doznania. [...] Problem polega nie na tym, że telewizja przedstawia nam rozrywkową tematykę, ale na tym, że wszelka tematyka przedstawiana jest jako rozrywka. Życie przedstawiane jest w konwencji nieustannej gry i zabawy. Prezenter, po dawce obrazów wojny, patologii, przemocy, z uśmiechem na twarzy zaprasza nas: „Zostańcie Państwo z nami, jutro znów będziemy razem i jutro będzie jeszcze piękniej niż dziś" ${ }^{\prime 1}$.

\footnotetext{
${ }^{10}$ Papieska Rada, dz. cyt., nr 13.

${ }^{11}$ N. Postman, Zabawić się na śmierć. Dyskurs publiczny w epoce show-businessu, przeł. L. Niedzielski, Wydawnictwo Muza, Warszawa 2002, s. 130.
} 
Ludziom grozi niebezpieczeństwo poddania wszelkich treści przekazu totalnemu entertainment, w którym chodzi przede wszystkim o komercję, dobry show, o tanią zabawę. Pierwszorzędnie nie chodzi o miłość, prawdę i wychowanie, ale o - jak to nazwał Hans Arp - ,kolektywną ekstazę i szybkie zarobienie pieniędzy"'12. Trzeba zauważyć, że opisane przez Postmana procesy degradacji i eliminacji racjonalnego dyskursu z mediów nie są zdeterminowane przez samą „naturę” przekazów medialnych, a więc nie przez formy językowe, lecz raczej przez treść przekazu i procesy komercjalizacji mediów. Postman pokazuje, że we wszechwładnej epoce mediów i ,show-biznesu”'13 życie prezentowane czy odgrywane na ekranie okazuje się ważniejsze od rzeczywistości, a medialne emocje skutecznie redukują świat ludzkich przeżyć. Jednym z często używanych przez media narzędzi grania emocjami jest epatowanie odbiorcy skrajnymi formami i treściami o dużej dawce negatywnych wartości, do których należy przede wszystkim wrogość i nienawiść.

\section{Odpowiedzialność w sumieniu za jakość mowy}

Poszukiwania narzędzi i sposobów ograniczania medialnej mowy nienawiści wskazują na potrzebę etyki mediów, która nie jest tylko postulatem refleksji etycznej nad mediami, ale również koniecznością, uwarunkowaną wieloma różnymi faktorami i służącą prawdzie i dobru człowieka oraz społeczności. Człowiek i społeczność stająca wobec wielu wyzwań kulturowo-medialnych tym bardziej potrzebują klarownej orientacji, by się nie zagubić w obszarach ,,nieprzyjaznych człowiekowi" (przemoc, agresja, fanatyzm, degradacja godności ludzkiej, nienawiść) oraz by się utwierdzić w słuszności posiadanego lub budowanego świata wartości.

Kiedy poszukujemy podstaw i uwarunkowań wolności słowa, stanowiącej ramy, w której może pojawić się także mowa nienawiści, to trzeba jasno powiedzieć, że realizuje się ona zasadniczo w sferze wewnętrznej człowieka, w sferze indywidualnej decyzyjności i wyborów warunkowanych zasadami etycznymi, stojącymi na straży wartości. Dokonuje się to w sferze wewnętrznej człowieka, w sumieniu. Wolność słowa jest zatem sprawą ludzkiego sumienia. Wskazują na to różne terminy, takie jak: ,podmiotowa świadomość moralna”, ,indywidualna odpowiedzialność”, „działanie zgodne z sumieniem”, „zgodne z wewnętrznym przekonaniem". Wiele z tych określeń, wskazując na człowieka jako jedyne

${ }^{12}$ Cyt. za: S. Babolin, Produzione di senso, Hortus Conclusus, Roma 1999, p. 156.

${ }^{13}$ Por. N. Postman, Das Zeitalter des Showbusiness, [in:] Kursbuch Medienkultur. Die maßgeblichen Theorien von Brecht bis Baudrillard, Hrsg. C. Pias, J. Vogl, L. Engell, O. Fahle, B. Neitzel, DVA, Stuttgart 2000, S. 223-233. 
i ostateczne źródło wartościowania, jest wyrazem postępującej subiektywizacji i relatywizacji etyki. Problemem bowiem nie jest to, że człowiek dokonuje subiektywnych wyborów. Wartościowanie etyczne, które się dokonuje w sumieniu człowieka, ma zawsze wymiar subiektywno-podmiotowy. Problemem natomiast jest to, czy człowiek wybierający i działający „zgodnie z sumieniem” ma sumienie prawdziwe, czyli właściwie uformowane. Podstawową troską każdej etyki winno być to, żeby ludzie mieli „sumienie ukształtowane zgodnie z prawdą”. Podstawą właściwych ocen etycznych jest bowiem sumienie pewne i prawdziwe. Takie prawdziwe sumienie staje się - w naszym rozumieniu - najważniejszą instancją medialną. Pozwala ono bowiem urzeczywistniać wolność człowieka, wolność słowa, a więc odkrywać i przekazywać prawdę w kontekście innych wartości ${ }^{14}$.

\section{Zakończenie}

W kontekście medialnego języka nienawiści pojawia się kilka wniosków o charakterze postulatywnym i związanych z nimi otwartych pytań.

1. Język mediów coraz częściej nie jest nośnikiem obiektywnych znaczeń, ale staje się narzędziem dyskursu komunikacyjnego. Sens słów jest tworzony w dyskursie komunikacyjnym. Język medialny staje się w konsekwencji narzędziem gry, dyskursu, dowolności i subiektywności ludzkich konstrukcji myślowych oraz autonomiczności w ich konstruowaniu, poznawaniu i praktycznym stosowaniu. Powstaje zatem pytanie, w jakim stopniu przekazy medialne tworzące obrazy świata odzwierciedlają faktyczny stan trudnych relacji społecznych prezentowanych językiem nienawiści i odwrotnie - w jakim stopniu wpływają one na kreowanie takich stanów sporów, kłótni i nienawiści w realnym świecie człowieka?

2. Po drugie, pluralizm aksjologiczny i różnorodność kryteriów wartościowania implikują także różnorodność form, treści, kontekstów i granic przekazów medialnych. Powstaje pytanie, czy, jak i w jakim stopniu ta różnorodność może i winna być postrzegana jako bogactwo poznawcze i aksjologiczne człowieka i bogactwo kultury, a pluralizm jako różność dyskursów komunikacyjnych na fundamencie uniwersalnego szacunku dla wartości i godności każdego człowieka, a nie jako chaotyczne przekraczanie granic dobrego smaku, przyzwoitości i elementarnego szacunku dla ludzi.

3. Po trzecie, procesy uśredniania medialnego i ułatwiania percepcji eliminują systematycznie potrzebę wysiłku intelektualnego w procesie odbioru treści

${ }^{14}$ Por. M. Drożdż, Osoba i media. Personalistyczny paradygmat etyki mediów, Wydawnictwo Diecezji Tarnowskiej Biblos, Tarnów 2005, s. 175-192. 
medialnych oraz pozbawiają człowieka samodzielnego myślenia. Czy w takiej sytuacji człowiek-odbiorca nie będzie utrwalał w sobie postaw konformizmu, lenistwa intelektualnego, spirali milczenia, rezygnując z własnej odpowiedzialność za kształt swojego logosu i etosu życia, wpisując się i posługując się preferowanym przez media światem rozrywki tworzonej językiem sporów i kłótni?

4. Po czwarte, media preferują nową jakość przekazów medialnych i nową jakość percepcji warunkowanych przede wszystkim formułą zabawy, lekkości, łatwości, rozrywki. Powstaje zatem pytanie, czy w takim świecie zabawy nienawiścią człowiek jest w stanie budować relacje do drugiego człowieka na fundamencie miłości i szacunku dla godności człowieka?

\section{Bibliografia}

Babolin S., Produzione di senso, Hortus Conclusus, Roma 1999.

CBOS, Społeczna percepcja przemocy i mowy nienawiści. Komunikat z badań, http://www.cbos. pl/-SPISKOM.POL/2007/K_074_07.PDF [dostęp: 14.06.2015].

Drożdż M., Logos $i$ ethos mediów. Dyskurs paradygmatyczny filozofii mediów, Wydawnictwo Diecezji Tarnowskiej Biblos, Tarnów 2005.

Drożdż M., Media. Teorie i fikcje, Wydawnictwo Jedność, Kielce 2005.

Drożdż M., Osoba i media. Personalistyczny paradygmat etyki mediów, Wydawnictwo Diecezji Tarnowskiej Biblos, Tarnów 2005.

Iłowiecki M., Pilnowanie strażników. Etyka dziennikarska w praktyce, Fronda PI, Warszawa 2012.

Jan Paweł II, Homilia wygłoszona w czasie Mszy św. w Olsztynie, 6 czerwca 1991 roku, [w:] Jan Paweł II, Pielgrzymki do Ojczyzny. Przemówienia i homilie, wyd. 3, Wydawnictwo Znak, Kraków 2005.

Jan Paweł II, Prawdziwi chrześcijanie i znakomici dziennikarze, http://www.opoka.org.pl/biblioteka/W/WP/jan_pawel_ii/przemowienia/dziennikarze_04062000.html [dostęp: 20.09.2006].

Kowalski S., Tulli M., Zamiast procesu. Raport o mowie nienawiści, W.A.B, Warszawa 2003.

Orliński W., Wolność stowa, także kłamliwego, „Gazeta Wyborcza” 2006, 1.03, s. 19.

Papieska Rada ds. Środków Społecznego Przekazu, Etyka w mediach, Watykan 2000.

Postman N., Das Zeitalter des Showbusiness, [in:] Kursbuch Medienkultur. Die maßgeblichen Theorien von Brecht bis Baudrillard, Hrsg. C. Pias, J. Vogl, L. Engell, O. Fahle, B. Neitzel, DVA, Stuttgart 2000.

Postman N., Zabawić się na śmierć. Dyskurs publiczny w epoce show-businessu, przeł. L. Niedzielski, Wydawnictwo Muza, Warszawa 2002. 


\title{
Michał Drożdż
}

\section{The Hate Speech in Media Discourse}

\begin{abstract}
(Summary)
This article is an attempt to seek answers to the question of whether so-called hate speech in the media constitutes a reporting of facts and reflects real social and cultural life or pursues other aims, for example: the persuasive and manipulative creation of a desired reality innate in the functioning of a commercial and persuasive media. The author attempts from the axiological perspective of the media, as well as from the semiological and linguistic perspectives, to answer the question of what the role of media language is in shaping and promoting real attitudes of hostility and hatred, and conversely, how cultural and media tendencies shape hate speech in the media. The author does not analyse the material aspect of language, but rather tries to look critically at certain trends shaping new forms of media language that bear negative values.
\end{abstract}

Key words: hate speech, media, media ethics, hate, speech. 